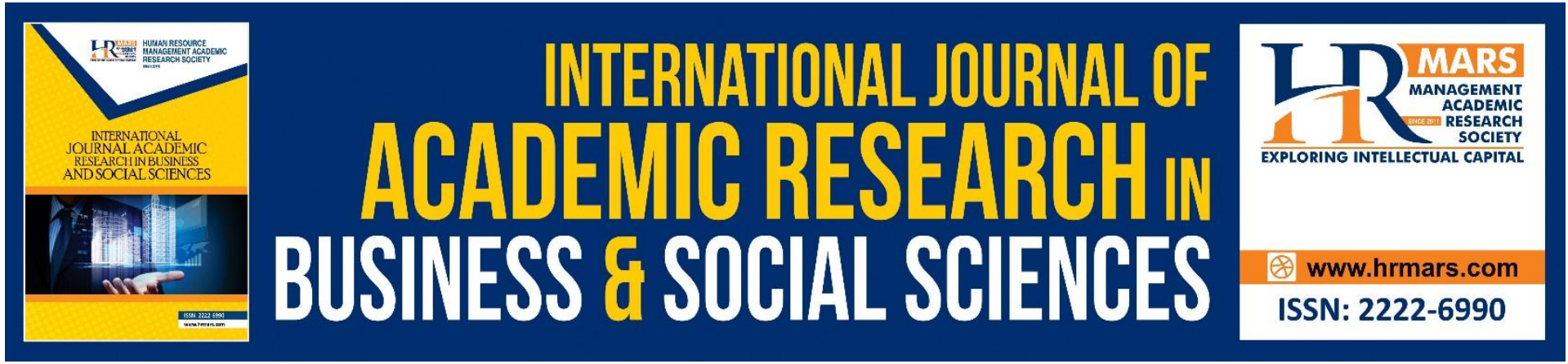

\title{
Issues and Challenges of Work Engagement among Lecturers
}

Nabilah Syuhada Nordin and Hazalizah Hamzah

To Link this Article: http://dx.doi.org/10.6007/IJARBSS/v11-i7/10206

DOI:10.6007/IJARBSS/v11-i7/10206

Received: 20 May 2021, Revised: 23 June 2021, Accepted: 09 July 2021

Published Online: 26 July 2021

In-Text Citation: (Nordin \& Hamzah, 2021)

To Cite this Article: Nordin, N. S., \& Hamzah, H. (2021). Issues and Challenges of Work Engagement among Lecturers. International Journal of Academic Research in Business and Social Sciences, 11(7), 1619-1625.

Copyright: (c) 2021 The Author(s)

Published by Human Resource Management Academic Research Society (www.hrmars.com)

This article is published under the Creative Commons Attribution (CC BY 4.0) license. Anyone may reproduce, distribute, translate and create derivative works of this article (for both commercial and non-commercial purposes), subject to full attribution to the original publication and authors. The full terms of this license may be seen at: http://creativecommons.org/licences/by/4.0/legalcode

Vol. 11, No. 7, 2021, Pg. 1619 - 1625

Full Terms \& Conditions of access and use can be found at http://hrmars.com/index.php/pages/detail/publication-ethics 


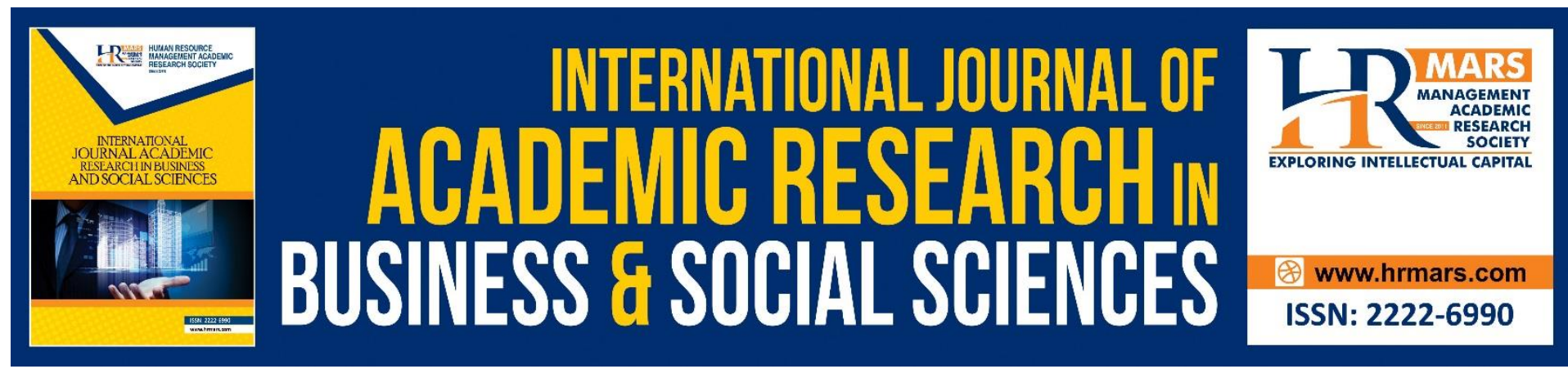

\title{
Issues and Challenges of Work Engagement among Lecturers
}

\author{
Nabilah Syuhada Nordin and Hazalizah Hamzah \\ Department of Psychology and Counselling, Human Development Faculty, Universiti \\ Pendidikan Sultan Idris, Malaysia. \\ Email: nabilahnordin181@gmail.com
}

\begin{abstract}
Lecturers' job scope is challenging and demanding. It can lead to undesirable behaviours within the academic practice if lecturers start to feel burdened by those job scopes. Hence, rather than solely focusing on performance, lecturers' engagement towards their tasks should be acknowledged. This article is attempting to discuss the issues and challenges related to the work engagement of lecturers by referring to previous articles. First, the concept of work engagement is described. Then, the reality of lecturers' engagement is explored. Then, it is followed by the current challenges within their job that might risk their engagement are included. This article concludes with a summary of the article and some recommendations for future researches. The significance of this article is that proper measures can be planned and administered starting from the management level until the individual level which is the lecturers themselves so that work engagement can be attained.
\end{abstract}

Keywords: Work Engagement, Lecturers, Job Demand

\section{Introduction}

Lecturers' responsibilities are beyond teaching. Lecturer is known as a profession with a demanding job scope mainly comprising of teaching, research activities and other services to the community. Each university all around the world would provide a detailed job description which includes other important elements namely supervision, consultation and publication. On top of these elements, lecturers are also involved in managing the program and other faculty activities. Then, lecturers' performance on these duties would be reflected on their Key Performance Indicator (KPI) score. For lecturers, the KPI achievement will not only determine their annual performance. The KPI is one of the factor that ensure their career to strive since it will determine their qualifications for promotions and the continuation of their job especially for contract lecturers. Hence, often times lecturers feel challenged and pressured to cater to these job demands.

Work engagement refers to the positive and fulfilling state of mind that can be identified as the combination of three dimensions which are vigor, dedication and absorption (Schaufeli et al., 2002). Basically, vigor refers to being energetic, dedication is being strongly involved and absorption refers to being concentrated and experiencing difficulties to leave work. This article is attempting to review the issues and challenges relating to lecturers' work 
engagement. The next section will first introduce work engagement as a relevant construct in the industrial and organizational psychology. Then, the issues related to the work engagement of lecturers are also be reviewed. Only then the challenges to maintain work engagement are shared.

\section{Issues of Work Engagement among Lecturers}

Work engagement is one of positive constructs in the field. The concept of work engagement has been prominent in organizational behavior studies especially within business and consultancy sectors. In studies, this construct is referred under slightly different terms such as employee engagement personal engagement and engagement.

The earliest concept is personal engagement which refers to the behavior of when individuals bring themselves in when they were performing job tasks at work place (Kahn, 1990). The main elements of personal engagement are the employment of self and the expressions of self. In addition, engaging behavior also refers to the physical, mental and cognitive commitment employees give to their job (Kahn, 1990). Meanwhile, an extension to Kahn's conceptualization of work engagement was introduced to finalize a more comprehensive definition of the construct. According to Schaufeli et al (2002), work engagement is characterized as the utilization of vigor, dedication and absorption during the employment of tasks. Schaufeli et al (2002) were also took importance on the operational aspect of work engagement hence an instrument to measure the construct was also established.

However, work engagement is also described as the combination of several positive constructs in work place such as job performance, job productivity and commitment to the organizations. Holbeche and Matthews (2002) described work engagement as a concept that includes feelings, emotional and intellectual relationship, job performances, productivity and commitment ones have for the organization. Hence, work engagement can be regarded as both cause and effect which comprised of the compilation of multiple job-related terms that characterized as different aspects of the construct.

Work engagement is one of the prominent subject in studies in the context of corporate sectors. The focuses of these studies are mainly on determining the factors that can maintain work engagement among their employees (lqbal et al., 2017; Yongxing, Hongfei \& Baoguo, 2017). For instance, a study was conducted to examine several relevant constructs that expected to have significant association with work engagement of their customer service employees (Yongxing et al., 2017). Studies on work engagement can also be traced in other contexts such as public sector (Kim, Han \& Park, 2019) and service sector like nursing (Othman, Ghazali \& Nasurdin, 2018) and teaching (Poortvliet, Anseel \& Theuwis, 2015). This showed that work engagement is important in wide variety of professions hence the concern on the engagement of lecturers is a relevant topic to be discussed.

As expected, excessive job demands are commonly associated with dysfunctional behaviors at workplace. Past studies showed that the mental health issues and emotional strains caused by work pressures can influence their productivity and performance (Malik \& Noreen, 2015; Yang et al., 2016). Meanwhile, other issues such as the tendency to be involved with predatory journals can be seen out of the desperation to simply attain the burdening KPI requirements. This undesirable action will be resulting losses for the university and country as the contributions of the great research findings to the community would not be utilized in correct ways (Hasnan, 2021). This reality showed that lecturers are struggling to complete their annual KPI. The worst outcome of the excessive job demands is burnout. Bakker and 
Demerouti (2017) argued that job demands can create a health-impairment process that can lead to burnout as illustrated in the Job Demands-Resource Theory.

However, the negative effects of job demands can be reduced by job resources and personal resources (Bakker \& Demerouti, 2017). This will generate the motivational pathway that lead to work engagement rather than burnout. Eventually, the ultimate goal of this theory is performance. Work engagement will result in high performance while burnout will risk performance. Therefore, instead of focusing on lecturers' performance, their work engagement should be concentrated on. One of the suggestions for the previous issues within the profession of lecturer is that the KPI should be reassessed to be challenging but not burdening (Hasnan, 2021). Hence, the advantage of challenging job duties in maintaining lecturers work engagement can be observed.

As introduced in the previous section, lecturers' job responsibilities are challenging thus their level of work engagement might become an issue. However, studies showed that lecturers reported high level of engagement to their job (Harini, Luddin \& Hamidah, 2019; Hamzah et al., 2021). This can be attributed to how lecturers view their duties such as research and teaching activities as their honourable contributions to the society as discussed by Harini et al (2019). They added that vigour and dedication dimensions are especially high showing that lecturers have positive feelings about their duties. This might be due to how their works namely research findings, publications and their students' achievements can give them the sense of pride thus causing them to be able to stay energetic, persistent and giving their full effort to whatever duties they were given. Still, are there any other factors that can influence lecturers' work engagement?

Past studies showed that supervisor support (Hamzah et al., 2021) and university management support (Agbionu, Anyalor \& Nawali, 2018; Alzyoud, Othman \& Isa, 2015) influenced the work engagement of lecturers. Lecturers also value supports from those around them for example in the form of autonomy and feedback (Alzyoud et al., 2015). However, it is important to note that lecturers are professionals that do not require excessive instructions from their supervisors or superiors in order to properly engaged to their work. Studies showed that lecturers valued the trust (Tauhed et al., 2018) and the chance to take part in decision making (Alzyoud et al., 2015; Tauhed et al., 2018) given by their supervisors. Such support could increase lecturers' involvement to their tasks hence increasing their engagement. These characteristics provided a conducive environment that ideal for lecturers to maintain their engagement to tasks.

\section{Challenges of Work Engagement among Lecturers}

Previous section showed that work engagement was reported among lecturers who tend to experience positive feelings toward their duties and those who received conducive work environment. It can be assumed that work engagement is the outcome of the reciprocity between lecturers and the university management as mentioned in some studies (Agbionu et al., 2018; Meilani, 2017; Tauhed et al., 2018). However, this does not mean that lecturers are not burdened by the job demands in the profession.

Apparently, lecturers are constantly challenged by the changes made in their KPI to match the guidelines provided by the government. For example, the KPI of Malaysian lecturers has to be reassessed to match the demands stated by the Ministry of Higher Education Malaysia. As such, the government is aspired to increase the quality of the overall system of higher institutions by increasing their ranking for research output and increasing 
the number of international students' enrolment. Thus, lecturers' expectation will be higher with time which would take toll on their current work engagement.

Other than that, lecturers are also affected during this pandemic. Remote learning, distance learning or online learning are becoming the most helpful alternative in this harsh situation where all people has to protect themselves and their family. This reality is not only challenging to students but also to lecturers. Will their engagement to their teaching duty be threatened? Studies showed one of the top issues in online learning is that lecturers lack of technical skills and inappropriate teaching styles adapted during class (Coman et al., 2020). Other challenges such as the dependence on media that enable e teleconferencing, telecommuting and online learning can also cause stress and burnout to lecturers (Mheidly, Fares \& Fares, 2020). Therefore, the struggle to maintain their engagement to their teaching duties can be threatened.

\section{Conclusions and Future Recommendation}

This review explored three issues related to work engagement among lecturers. First, it was found that there are multiple attempts to conceptualize the term work engagement. It can be concluded that work engagement is related to bringing oneself into tasks (Kahn, 1990) which require vigorousness, dedication and being absorbed into tasks (Schaufeli et al., 2002). Naturally, lecturers' job demands are a threatened to their work engagement. However, based on this review, studies showed that lecturers possess high level of work engagement due to several factors such as their positive feelings towards their duties and the conducive environment provided at their work places. However, there were a couple of challenges that might be faced by lecturers. The review on the challenges in lecturers' job scopes showed that lecturers will be constantly facing new obstacles throughout their career such as the government aspirations and the pandemic. Thus, lecturers' work engagement would be threatened.

Online teaching is becoming the main option in this pandemic hence the issue regarding lecturers' work engagement has to be studied. Hence, few suggestions are included in this article. First, the studies on lecturers' satisfaction on online teaching has to be examined. Lecturers' job satisfaction is associated with work engagement (Meilani, 2019) hence a study on the topic is recommended. A previous paper on lecturers' satisfaction about the institution readiness to provide essential facilities and aids for online teaching has been conducted (El Refae, Kaba \& Eletter, 2021). Their result showed that the participated lecturers are satisfied with the institutional readiness. Still, it is suggested that the relationship between job satisfaction and work engagement during online teaching should be determined.

Second, the studies on lecturers' work engagement to other elements within the job scopes should be discussed too. Studies during pandemic has been surrounded around the teaching element of their job scopes (Coman et al., 2020; El Refae et al., 2021; Mheidly et al., 2020). Pandemic has also causing changes to the way lecturers' do their work such as the way researches were conducted and how conferences have been held. Thus, it is suggested to explore the exact issues faced by lecturers in order to determine their level of engagement in the new normal.

\section{References}

Agbionu, U. C., Anyalor, M., \& Nwali, A. C. (2018). Employee engagement and performance of lecturers in Nigerian. Journal of Education \& Entrepreneurship, 5(2), 69-87. https://doi.org/10.26762/jee.2018.40000015 
Alzyoud, A. A. Y., Othman, S. Z., \& Isa, M. F. M. (2015). Examining the role of job resources on work engagement in the academic setting. Asian Social Science, 11(3), 103-110. https://doi.org/10.5539/ass.v11n3p103

Bakker, A. B., \& Demerouti, E. (2017). Job demands-resources theory: Taking stock and looking forward. Journal of Occupational Health Psychology, 22(3), 273-285. https://doi.org/ 10.1037/ocp0000056

Coman, C., Tîru, L. G., Meseșan-Schmitz, L., Stanciu, C., \& Bularca, M. C. (2020). Online teaching and learning in higher education during the coronavirus pandemic: Students' perspective. Sustainability, 12(10367). https://doi.org/10.3390/su122410367

El Refae, G. A., Kaba, A., \& Eletter, S. (2020). Distance learning during COVID-19 pandemic: satisfaction, opportunities and challenges as perceived by faculty members and students. Interactive Technology and Smart Education. https://doi.org/ 10.1108/ITSE08-2020-0128

Hamzah, H., Nordin, N. S., Dwiyanti, R., Na'imah, T., \& Mawi, N. (2021). The role of well-being, supervisor support and positive feedback on lecturers' work engagement. The Journal of Behavioral Science, 16(1), 73-84. https://so06.tcithaijo.org/index.php/IJBS/article/view/245504

Harini, S., Luddin, M. R., \& Hamidah (2019). Work life balance, job satisfaction, work engagement and organizational commitment among lecturers. Journal of Engineering and Applied Sciences, 14(7), 2195-2202.

https://doi.org/10.36478/jeasci.2019.2195.2202

Hasnan, H. A. (2021). 'Taksub' terbitkan makalah: KPI pensyarah perlu berteras negara, masyarakat-MPN. Astro Awani. https://www.astroawani.com/berita-malaysia/kpipensyarah-perlu-mencabar-namun-tidak-hingga-membebankan-apm-283563

Holbeche, L., \& Matthews, G. (2002). Engaged: Unleashing your organization's potential through employee engagement. San Francisco: John Wiley \& Sons Ltd.

Iqbal, J., Shabbir, M. S., Zameer, H., Khan, I. A., \& Sandhu, M. A. (2017). Antecedents and consequences of employee engagement: Evidence from corporate sector of Pakistan. Paradigms: A Research Journal of Commerce, Economics, and Social Sciences, 11(1), 78-86. https://doi.org/10.24312/paradigms110113

Kahn, W. A. (1990). Psychological conditions of personal engagement and disengagement at work. Academy of Management Journal, 33(4), 692-724. https://doi.org/10.5465/256287

Kim, W., Han, S. J., \& Park, J. (2019). Is the role of work engagement essential to employee performance or 'nice to have'? Sustainability, 11, 1050-1066. https://doi.org/10.3390/su11041050

Malik, S., \& Noreen, S. (2015). Perceived organizational support as a moderator of affective well-being and occupational stress. Pakistan Journal of Commerce and Social Sciences (PJCSS), 9(3), 865-874. http://hdl.handle.net/10419/188227

Meilani, Y. F. C. P. (2017). Factoring employee engagement of full time lecturers [Paper presentation]. Parahyangan International: 3rd Accounting \& Business Conference 2017, Bandung. http://piabc.fe.unpar.ac.id/

Mheidly, N., Fares, M. Y., \& Fares, J. (2020). Coping with stress and burnout associated with telecommunication and online learning. Front. Public Health, 8(574969). http://dx.doi.org/10.3389/fpubh.2020.574969 
Othman, N., Ghazali, Z., \& Nasurdin, A. M. (2019). Enhancing nurse engagement: The role of social support and job characteristics. The Turkish Online Journal of Design Art and Communication, 8, 1285-1282. https://doi.org/10.7456/1080SSE/172

Poortvliet, P. M., Anseel, F., \& Theuwis, F. (2015). Mastery-approach and mastery-avoidance goals and their relation with exhaustion and engagement at work: The roles of emotional and instrumental support. Work \& Stress, 29(2), 1-21. http://dx.doi.org/10.1080/02678373.2015.1031856.

Schaufeli, W. B., Salanova, M., González-Romá, V., \& Bakker, A. B. (2002). The measurement of engagement and burnout: A two sample confirmatory factor analytic approach. Journal of Happiness Studies, 3(71). https://doi.org/10.1023/A:1015630930326

Tauhed, S. Z., Rasdi, R. M., Samah, B. A., \& Ibrahim, R. (2018). The influence of organizational factors on work engagement among academics at Malaysian research universities. International Journal of Academic Research in Business and Social Sciences, 8(10), 973-988. http://dx.doi.org/10.6007/IJARBSS/v8-i10/4793

Yongxing, G., Hongfei, D., Baoguo, X., \& Lei, M. (2017). Work engagement and job performance: the moderating role of perceived organizational support. Anales de Psicología, 33(3), 708-713. http://dx.doi.org/10.6018/analesps.33.3.238571

Yang, L. Q., Liu, C., Nauta, M. M., Caughlin, D. E. \& Spector, P. E. (2016). Be mindful of what you impose on your colleagues: Implications of social burden for burdenees' wellbeing, attitudes and counterproductive work behaviour. Stress and Health, 32(1), 7083. http://dx.doi.org/10.1002/smi.2581 